\title{
Facing the Future: On the Way to New College Library Standards
}

$\mathrm{T}$ WELVE YEARS have passed since the College and University Postwar Planning Committee under William H. Carlson's chairmanship recommended "that special concern and attention be devoted to those libraries, constituting the large majority of all higher educational libraries in the land, which clearly fall below accepted levels of support and that continued attention be given to developing standards and norms which will assist these libraries in improving their staffs, book stock, and service."1 Nobody can deny that considerable progress has been made at numerous institutions in the meantime. But anybody who has visited some of the less famous college libraries in the country is aware of the fact that they are still struggling against tremendous odds. Every administrator proclaims, of course, publicly that he considers the library to be the heart of his college, but a careful examination of the budget allocations will sometime lead to different conclusions. The present writer had some opportunity to observe this discrepancy, when he was a member of the New York Board of Regents' Committee on the Integration of College and University Library Resources and, more recently, while serving on evaluation teams for the Middle States Association of Colleges and Secondary Schools.

His impressions have been confirmed

1 College and University Postwar Planning Committee of the ALA and ACRL. College and University Li. braries and Librarianship. Chicago: ALA, 1946, p. 21.

Dr. Hirsch is Librarian and Professor of History at Trenton State College. At present, he is Chairman of the ACRL Committee on Standards. by many letters from college librarians; e.g., the chairman of a regional committee on standards wrote him a few months ago: "Our study of the standards in ... has so far revealed only their almost complete absence." An analysis of the annual statistics published in $C R L$ presents even more comprehensive corroborating evidence. While some of our leading colleges support their libraries generously, there are still far too many cases, where obviously the salaries are too low, and the collections are starved. This would be perilous at any time, but it creates the gravest apprehension now, because college libraries must face the obligations created by rapidly rising enrollments. If we do not agree on new standards soon, and make every effort to implement them, many college students of the nineteen-sixties will be served by disgruntled, completely overworked librarians in overcrowded buildings and will look in vain for that variety of good up-to-date reading materials without which no solid papers can be written nor any real learning be accomplished. ${ }^{2}$

Considerations of this kind were probably in the minds of the ACRL Board of Directors, when they authorized, at their meeting in Kansas City last June, the new chairman of the ACRL Committee on Standards to start work on new college library standards. The committee, under its previous chairman, Dr. Wayne S. Yenawine, had laid some

2 Some of the broader issues were presented by $\mathrm{Wy}$ man W. Parker of Wesleyan University in his ex. cellent paper on "College Library Standards and the Future" at the Conference of Eastern College Librar ians, Columbia University, November 30, 1957. This writer is in full agreement with Mr. Parker's basic points. 
groundwork for this larger job by preparing two publications, a bibliography on college library standards ${ }^{3}$ and a compilation of accrediting standards. ${ }^{4}$ The committee began work on its new assignment in the early fall of 1957. Its members are librarians from institutions of various types and from different regions, ${ }^{5}$ but they easily reached agreement on some fundamental issues. They held a full-day work session at the ALA Midwinter meeting in Chicago on January 27, 1958. A set of suggestions presented by the chairman served as the basis of frank and lively discussions. In the afternoon the committee was joined by twenty-seven outstanding college and university librarians. Nineteen states from Massachusetts to California were represented in the room and all types of academic institutions were included. ${ }^{6}$ This open meeting was extraordinarily successful in clarifying the issues. The committee received a great deal of sage counsel and strong encouragement for its efforts. That same night the committee planned the next steps in the light of the advice given by these experts. The work on the first draft of the new standards was divided up and an early date set for its completion. This draft will be submitted to the twenty-seven experts, to some other prominent librarians, to the spokesmen of the regional ac-

${ }^{3}$ List of Writings on College Library Standards, 1930. 1954. Compiled by David C. Weber, 1956. Available free of charge from the office of the librarian, Trenton State College.

${ }_{4}^{4}$ College and University Library Accreditation Standards-1957. Compiled by Eli M. Oboler, Ruth Walling and David C. Weber. A.C.R.L. Monograph no. 20. Chicago: A.C.R.L., 1958.

5 Mrs. Minnie R. Bowles, Hampton Institute; Miss Helen M. Brown, Wellesley; Mrs. Katharine Brubeck,

Baltimore, Maryland; Mr. Eugene A. Holtman, Ohio

Baltimore, Maryland; Mr. Eugene A. Holtman, Ohio

linois University; Miss Ruth Walling, Emory University.

Present were: Martha Biggs, Paul Bixler, Arna Bontemps, Clyde Cantrell, H. Vail Deale, Walfred Erickson, J. W. Gordon Gourlay, Charles F. Gosnell, John F. Harvey, Harold W. Hayden, Edward C. Heintz, Robert Hertel, Esther Hile, W. Śtanley Hoole, John H. Lester, Flora Belle Ludington, A. H. Mattlin, Ralph W. McComb, Jean McFarland, Eli Oboler, Alice E. Paine, Katharine Stokes, R. C. Swank, Donald E. Thompson, Eileen Thornton (President of ACRL), Fritz Veit, Eugene P. Watson. crediting agencies, and to some academic administrators for their criticisms and suggestions. Then a second draft will be prepared by the committee in late spring. This second draft is to be presented at the ALA meeting in San Francisco for public discussion. The committee hopes, if all goes well, for an adoption of the new standards at the ALA Midwinter Meeting in January, 1959 or, at the latest, at the ALA Conference in Washington.

While the committee is at work, it may benefit greatly from suggestions coming from the ACRL membership. Each time that this writer has discussed the problem of standards with groups of college librarians, ${ }^{7}$ valuable new points were raised by some of them; everywhere he was assured that the work of the committee is timely and indeed urgent. Based on these heartening experiences, he invites comments from fellow librarians prior to the San Francisco Conference; every constructive suggestion will be taken up by the committee. The new standards will fulfill their function over a longer period of years only if they embody the best thinking of the profession.

The committee does not aim to prepare an all-inclusive document. Nothing on the order of the Classification and Pay Plans for Libraries in Institutions of Higher Education (Chicago: A.L.A., 1942 and 1947) is under consideration. While this set of documents had great merits, it is felt that the profession needs today a much simpler and more flexible tool. The new standards will be phrased so that their implications can be easily grasped by busy college administrators and by the lay members of boards of education, trustees, etc. In some respects, the forceful language used in Public Library Service: $A$ Guide to Evaluation, with

\footnotetext{
7 This paper presents the essence of different speeches before the ACRL Teacher Education Libraries Section, the ACRL Philadelphia chapter and the College and University Libraries Section of the New Jersey $\mathrm{Li}$ brary Association.
} 
Minimum Standards (Chicago: A.L.A., 1956) may be taken as an example. Also Document No. 4.81 of the Middle States Association Evaluating the Library (October, 1957) should be suggestive; it has indicated to what type of questions the new standards must provide the proper answers.

Something could be said in favor of standards which would embrace all types of college and university libraries. But consultation with some leading university librarians led to the conclusion that the disadvantages of an all-inclusive document would outweigh the benefits. The basic problems of the small liberal arts college or teachers college library are so different from those of the large research library that it is almost impossible to find a common denominator. Therefore, it was decided that the new standards should apply only to those institutions which confine themselves to undergraduate instruction and/or graduate work on the master's level. Not only the research libraries were omitted, but also the junior college libraries, since separate standards for them have just been prepared and should be published shortly.

The new standards will center around the formulation of principles. But they will also contain precise proposals on certain key issues. The committee felt (and many of the outside experts concurred) that struggling college libraries will be helped effectively only if there are clear expectations for staff-size, financial support, seating capacity, etc. Frequent reference will be made to the annual statistics published in $C R L$ since they provide the most up-to-date information. It may be considered as a danger signal if a library consistently receives support below the median level indicated for institutions of its kind. However, no dollar sign will appear in the new standards, since the real value of our currency has so frequently changed.
Instead, it will be stated that normally a college library should receive 5 to 7 per cent of the total educational budget of the institution. This is not an excessively high percentage. Some of the college libraries with a long-established tradition of excellence receive more than 6 per cent of the educational budget, e.g., Haverford (9.7), Dartmouth (6.8), Swarthmore (6.73), Wesleyan University (6.54) and Vassar (6.31). The committee recognizes that this percentage may be hard to maintain in libraries of institutes of technology; even the M.I.T. library receives only 2.7 per cent of the total budget. But the demand for 5-7 per cent offers the most effective protection for all other types of academic libraries. In a period of rapid expansion, of course, even 7 per cent may not be enough to build up a college library properly and speedily. The committee does not plan to suggest any formula for the allocation of the library budget for specific purposes; it depends primarily on local circumstances, what slices of the budget will be used for salaries, books, periodicals, equipment, etc. The ultimate responsibility for the proper apportionment must rest with the librarian; an unwise distribution will be a reflection on him.

The proposed standards for the structure and government of the college library should not arouse much argument. The committee believes that the librarian should be directly responsible to the president or the head of the academic program of the institution. The lines of authority should be clearly drawn. The faculty library committee should be strictly limited to advisory functions. While the librarian must assume responsibility for the administration of the library, he should seek the advice of his staff on all important matters of policy and procedure.

More controversial will be some of the proposed standards for the staff, its size, and status. The committee urges 
that every college library should have a minimum of three professional librarians, i.e., the head librarian and two assistants in charge of processing and readers services respectively. While there may be extraordinary circumstances under which a college library may do an outstanding job with fewer professionals the minimum of three professional librarians should prevail as a rule. The committee believes that enrollment, rate of acquisitions, and instructional program determine the size of the staff. Therefore, it is hard to arrive at a rigid rule, but the staff formula developed by New York State University for its teachers colleges is quoted in the draft of the standards at least for its suggestive value. This formula has the virtue of drawing attention to the need for adequate utilization of non-professional staff; able clerical workers may handle effectively many assignments formerly reserved for professionals. The committee recommended that all professional librarians receive academic status and with it the same salary schedule and benefits enjoyed by the teaching faculty, such as tenure, sabbatical leave, and retirement provisions. However, equal privileges must be matched by equal responsibilities. For instance, if faculty promotions in an institution are based on advanced graduate work, professional librarians will have to follow the same pattern. The chief librarian should rank with other academic department heads; this seems obvious, but many colleges still relegate the librarian to an inconspicuous position.

It is the duty of the librarian to see to it that the book collection is stimulating and well rounded. It falls also to him to fight excessive duplication of titles, although standard works in heavy demand should be available in multiple copies. He can help protect intellectual freedom by securing a fair presentation of both sides on controversial issues. The com- mittee believes that the excellence of the book collection may be assured, if a library holds high percentages from certain standard lists, like the Lamont Library list, the list of reference books compiled by W. S. Hoole for the Southern Association of Colleges, R. R. Hawkins'Bibliography of Scientific, Medical and Technical Books published in the U.S.A., and certain sections of the Shaw list, especially in the humanities. It is not enough, however, that the library has books of enduring value and that they fit the curriculum; it must also have them in sufficient numbers if every student is to be given a fair opportunity. Therefore, the committee suggests a minimum size of the collection, based on the enrollment. Part-time extension students, usually the forgotten men on a college campus, are to be equated into full-time figures. A college with 600 students should have at least 40,000 volumes; 10,000 volumes should be provided for every 200 additional students, until the collection reaches about 300,000 volumes. Of course, generous special provisions must be made in an institution offering graduate or honors work.

The college library must also offer a comprehensive, carefully balanced, and intellectually stimulating choice of periodicals with adequate back files. Again some standard lists are to serve as yardsticks, e.g., E. I. Farber's Classified List of Periodicals for the College Library (Boston: F. W. Faxon, 1957.) This is the fourth edition of the list originally compiled by Guy $R$. Lyle. It is also the function of the college library to secure up-to-date materials in various areas of audio-visual education, if no instructional department of the college makes adequate provisions in this respect.

Another important part of the standards will deal with the library building. It should be centrally located and functionally designed. Seating accommoda(Continued on page 262) 


\section{New College Library Standards}

(Continued from page 200)

tions for 25-331/3 per cent of the student body will be suggested; allowance for differences between the residential and commuter colleges will be made. Shelf space should be provided to take care of growth for at least a decade.

Finally, the standards will urge close interlibrary cooperation along the lines suggested in A Plan for Meeting College Library Problems, the report of the Regents' Committee (Albany: State Education Department, 1954). A frequent evaluation of the library is also recommended. Library staff and teaching faculty should ascertain by joint efforts that the standards of service are high and that the library fulfills its educational tasks. This is no easy job, for how is one to measure the spirit of a library? The per capita circulation of books to students on two-week loan may offer some valuable clues; in fact, some educators, such as Henry M. Wriston, consider it the best index of an institution's intellectual health. But, owing to special local con$\Delta /$ ditions, this figure may not always provide a reliable yardstick and must, therefore, be used with considerable caution.

The ACRL Committee on Standards is well aware of the criticism that some of its proposals may provoke. New standards cannot please everybody; to do so they would have to be confined to vague generalities. The hour calls for vision and boldness. We must design standards which are high enough and flexible enough to protect and improve the position of the American college library as it faces the unprecedented challenge of the nineteen-sixties.

\section{Russian Bibliographical Guides}

(Continued from page 216)

lications, and several other categories of material. ${ }^{43}$

Another such union list is the justpublished Catalogue collectif des periodiques, ${ }^{44}$ put out by the Bibliotheque $\mathrm{Na}$ tionale in Paris, which lists the Cyrillic Slavic periodicals in the French university libraries, and in the Parisian libraries, as of 1950. The arrangement is alphabetical by title. Each entry is also provided with call numbers in the various libraries. This work was preceded by that of B. Unbegaun, ${ }^{45}$ which was pub-

13 For a detailed description of this work see: Constance M. Winchell, Guide to Reference Books, 7 th ed., Chicago, 1951. p.94.

14 Bibliotheque Nationale, Paris. Départment des periodiques. Catalogue collectif des periodiques conserves dans les bibliotheques de Paris et dans les bibliotheques universitaires de France, periodiques slaves en caracteres cyrilliques; etat des collections en 1950. Paris, 1956. 2 Vols.

${ }^{45}$ Unbegaun, Boris, Catalogue des periodiques slaves et relatifs aux etudes slaves des bibliotheques de Paris. Paris, 1929. 221p. (Published as Volume IX to Travaux publies par l'Institut d'etudes slaves.) lished in 1929. The latter lists all periodicals relating to Slavic affairs, in Slavic and other languages, available in the Paris libraries as of 1927.

In conclusion, we may say that once the Periodicheskaia Pechat' SSSR 19171949 is completed, we will have a complete registration of the periodicals of the twentieth century, up to the present time, as this work is the chronological continuation of the Predvaritel'nyi spisok periodicheskikh izdanii Rossii 19011916 , and in turn is continued by the Letopis' Periodicheskikh izdanii SSSR 1950-1954. Unfortunately this is not true of newspapers, as the Periodicheskaia Pechat' SSSR does not include these. For these, as well as for chronological guidance to periodicals, we shall still have to turn to the numerous annual bibliographies. 